combined to encourage their, use more often than the occasion warranted. The power to go to war at will was apt, in fact, to result in a thoughtless application of that power.

In the afternoon session Sir Trevor Dawson dealt with the future of airships. He thought there would be no difficulty in producing ships to travel at eighty miles an hour, thus giving an average speed, allowing for the wind, of sixty miles, and expressed the view that there would be no difficulty in running a regular trans-oceanic service once the trustworthiness and saving of time had been demonstrated. In his opinion, the time to the Cape might thus be reduced from eighteen days to five, and that to India from sixteen days to four or five.

Sir James Stevenson, Civil Member of the Air Council, stated towards the end of the discussion on behalf of the Ministry, and he thought he might say on behalf of the Government, that if a commercial syndicate would offer to take their airships and develop them as a national undertaking, it would be an easy matter to get the Government to agree to give them not only airships, but also aerodromes and the other assets.

A further resolution was passed asking the Government to reconsider the report of the Civil Aerial Transport Committee and the recommendations it contained with the view of adopting such as might now apply.

The confcrence, which was remarkable in many ways, closed with the usual votes of thanks, and in replying, Lord Londonderry, chairman at the concluding session, expressed the appreciation of the members for the help afforded by the Press.

There is no doubt that aviation, particularly civil aviation, will benefit from the discussions which have taken place, and still more from the fuller consideration which can be given to the papers when published in full. The hope was expressed by many that the conference may become an annual event, and thus afford a regular opportunity for the ventilation of questions of great public interest. $\quad$ R.T.G.

\title{
Annual Report of the Meteorological Committee. ${ }^{1}$
}

$\mathrm{T}^{\mathrm{H}}$

HE Report of the Meteorological Committee for the year ending on March 3I last marks the end of a definite stage in the development of the British State Meteorological Service. During the year under review four notable developments occurred: (I) The Office became attached to the Air Ministry instead of being in direct connection with the Treasury; (2) the work of the British Rainfall Organization was incorporated with that of the Office; (3) the co-ordination of the Services of the Navy, Army, and Air Force, which developed during the war, was begun; and (4) inter-Dominion and international co-operation in meteorology, which had largely been in abeyance during the war save for military purposes, began to take a more definite shape. One might add as a fifth important occurrence that the period of service of Sir Napier Shaw as Director of the Office came to an end at the close of the year, though he consented to remain in office until the appointment of his successor was carried through.

An appendix to the report gives the recommendations of the Sub-Committee of the Research Committee of the Cabinet which was appointed to lay down principles on which the State Meteorological Services should be reorganised. It is satisfactory that the wisdom of having one State organisation has been realised, and that while the constitution of the Committee provides for adequate representation of public Departments, the Royal Society and the Royal Society of Edinburgh are also represented. The constitution of the Committee provides that the Controller-General of Civil Aviation shall act as its chairman, but on the representation of the Royal Society it was agreed that a vice-chairman should be elected from amongst the representatives of scientific societies. The Director of the Office, who under the old régime was chairman of the Committee, ceases to be a member, but "will act generally as adviser to the Committee on all meteorological and geophysical subjects," and is made responsible for bringing before the Committee "all matters of importance relating to the application, progress, and development of the science of meteorology in which the Meteorological Service might share."

The British Rainfall Organization had a separate existence for sixty years, but it had for some time

1 Fifteenth Annual Report of the Meteorological Committee to the Lords Commissioners of His Majesty's Treasury for the Year ended March 3T, 1920. Pp 82. (Cmd. 948.) (London: H.M. Stationery Office, 1920.) Price 9 d. net.

NO. 2660 , VOL. I06] been evident that incorporation with the growing State Service was desirable, and indeed necessary, On the retirement of Dr. H. R. Mill from active duty as Director of the Organization, the transfer was carried through. Mr. Carle de S. Salter, who was associated with Dr. Mill, has been appointed superintendent of the rainfall work of the Committee, so that the continuity of the work and of the relations with voluntary observers is assured.

The overlapping of the various Meteorological Services which developed during the war was perhaps more apparent than real, but there cannot be two opinions as to the need for co-ordination under a central authority. The Navy, the Army, and the Air Force each had quite distinct and separate needs which were met by separate establishments, but the only serious overlapping which occurred arose from the creation of separate headquarters in London, provided with a staff for forecasting, and each collecting similar information. This overlapping has now, fortunately, disappeared, and a start has been made with the establishment of local civil distributive stations to take the place of war-time stations for supplying to aircraft, shipping, and the general public informa. tion derived from detailed study of the weather in a form suitable for practical use. One interesting development in this connection is the provision of an effective local organisation for Scotland, with head. quarters in Edinburgh and a local advisory committee.

The effect of the war in bringing to light the value of meteorological information is well gauged by the increase in the personnel of the Office. In I9I4 the staff of the Office comprised about 20 professional and 60 clerical and technical assistants, while on March 3I, I920, the establishment was 97 professional staff and 278 clerical and technical staff.

The inter-Dominion and international arrangements are still far from being stabilised, but one of the most important developments was a Conference of Dominion meteorologists. which concluded with the following resolution: "That this conference of representative meteorologists of the British Empire assembled together for the first time agree to continue as an association for the exchange of their views from time to time bv correspondence upon scientific matters con. cerning the achievements, requirements, and organisa. tion of their Services, and hereby elect Sir Napier Shaw their first president, and invite the members to submit rules for the guidance and acceptance of the 
association." This conference had been preceded by the international meeting in Brussels of representatives of the scientific academies of the Allies, at which meteorology was amongst the subjects considered. A Geodetic and Geophysical Union was set up, one of its branches being meteorology with Sir Napier Shaw as chairman and Dr. Marvin (of the U.S. Weather Bureau) as secretary. A meeting in Paris followed, summoned by the French Government, at which a new international meteorological committee was appointed, with Sir Napier Shaw as president, in continuation of the old committee. A further complication arises out of the convention relating to aerial navigation, which formed part of the work of the Peace Conference, and by Annexe G regulates "the collection and dissemination of statistical, current, and special meteorological information."

What shape international co-operation may ultimately take is sufficiently obscure, but it is satisfactory to know that Sir Napier Shaw, who has been responsible for so great a development in the past, is to continue to act as president of the new International Committee.

E. M. W.

\title{
Proposed British Institute for Geodetic Training and Research. ${ }^{1}$
}

\author{
By Dr. E. H. Griffiths, F.R.S., and Major E. O. Henrici.
}

GOOD maps are necessary for the development of a country, for such purposes as defining property boundaries, limits of mining and other concessions, and so on, as well as for such engineering purposes as railway, road, and canal schemes, hydro-electric schemes, water-supply, irrigation, etc. The importance of good charts, as well as of trustworthy information as to tides and currents, scarcely needs emphasising. An incorrect or out-of-date chart will cause losses due to delays to shipping, even if it does not lead to more direct loss. Anything that will assist in the production of up-to-date and accurate charts is of great and direct benefit to the shipping industry, and through it to the nation. Even when such work has once been completed there is no finality, as both maps and charts require periodical revision at more or less frequent intervals, according to circumstances.

The economical and speedy production of such maps and charts necessitates a thorough knowledge of the principles on which all survey work is based and of the best means of applying such principles under varying conditions. Apart from revision work, there is still a great deal of survey work waiting to be carried out, enormous areas still exist in the Empire which are surveyed very inadequately or not at all.

Very large sums have been misapplied in the past orving to a lack of appreciation of the principles which should underlie all survey work. The Egyptian Survey of $1878-88$ cost some 360 ,oool., and produced incomplete maps of some 2000 square miles. Almost the whole of the work had to be repeated in $1892-1907$, when, owing to the adoption of proper methods, and in spite of many difficulties, some 13,000 square miles were satisfactorily mapped at a cost of less than $450,000 l$.

The methods to be adopted depend upon circumstances, the nature of the country, and the objects of the survey. The difficulties to be overcome vary in different parts of the world. The experiences of the various surveyors have been published in their records and reports, but these are not in an easily accessible form, nor is there any general index or summary to be found. The originals are circulated to a limited number of persons and institutions, and buried in libraries, even if their existence is not forgotten. When a new difficulty arises in any survey it has to be tackled de novo, though it is quite likely that similar circumstances have arisen before. In such a case it is probable that the surveyor in question does not know of it; and, even if the reports are accessible to him (which they frequently are not), the

1 From an address on "The Urgent Need for the Creation within the Empire of a Central Inctitution for Training, and Research in the Sciences of Surveying, Hydrography, and Geodesy," delivered to a joint meeting of Sections $A$ and $E$ at the Cardiff meeting of the British Associa-
tion on August 27.

NO. 2660 , VOL. IO6] actual information he wants is most effectually buried. This leads to much waste of effort, as there is no central body to which he can refer.

As regards existing departments and institutions, the Dominion, Indian, and Colonial Surveys are all independent, and, broadly speaking, train their own staff. There are, however, good survey schools in some of the Dominions. The Ordnance Survey produces its well-known maps, which are revised periodically, and they are so complete that no extensive survey work is required by outsiders in. this country. This accounts for the lack of attention paid to the subject outside Government Departments, but the result has been that the development of the science of surveying has largely stagnated in this country, the centre of the Empire.

There is, therefore, a distinct need for a school and institution in which students can be trained in the principles of survey work, and where the subject is studied as a whole. This school would also serve as a central information bureau, enabling the scattered surveyors of the Empire to keep in touch with developments, and to which they could apply for information and assistance.

It might seem at first sight that this could and should be undertaken by a Government Department, but this is scarcely possible for various reasons. There is no central authority which deals with the Government Surveys of the Empire, though a link is kept between the Colonial (as distinct from the Dominion) Surveys by the Colonial Survey Committee. The various Surveys and Departments naturally have to consider their own immediate needs first; they are usually short of funds, and consequently not in a position to carry out the work now being discussed. Even if a central authority were formed for this purpose, it could deal only with Government Surveys, and could not train surveyors and engineers for private work.

There seems little doubt that most of the Government Surveys would welcome a school from which they could recruit their staff and an institution to which they could apply for information, and which could keep them in touch with the activities and progress in other parts of the world.

The existence of such an establishment would also encourage the production of improved designs of instruments and the production of new time-saving devices; there have been many such improvements of late years, but mostly from abroad, e.g. invar tapes and wires for base measurement (France) and an improved levelling instrument (Germany). There are also many developments in view which require working out, e.g. the use of wireless time-signals for the determination of longitude in the field, survey from aircraft, etc. At present makers have little 